\title{
Problems faced in distance education during Covid-19 Pandemic
}

\author{
Gül Özüdoğru* \\ Department of Educational Science, Kırşehir Ahi Evran University, Kırşehir, Turkey, \\ ORCID: 0000-0002-5128-1258
}

Article history

Received:

01.02.2021

Received in revised form: 08.04.2021

Accepted:

22.04.2021

Key words:

Covid-19;

Pandemic;

Distance education problems;

Pre-service teacher
This study aimed to investigate the problems faced by pre-service teachers in the distance education process, which has been implemented during the Covid-19 pandemic. The study was carried out as a case study of qualitative research methods. The study group comprised pre-service teachers receiving education in the faculty of education in a state university in Turkey during the spring term of the 2019-2020 academic year. In order to collect data, the researcher created an interview form. Then the form was applied to the pre-service teachers on a volunteer basis and online. The content analysis method was used in the data analysis. The data were coded by two researchers. Miles and Huberman's (1994) formula was used for a consensus between the coders. At the end of the study the problems experienced by the pre-service teachers were collected under the themes of implementation, student, impossibility, technical and instructor. The pre-service teachers stated that they mainly faced problems such as the lack of time spared for live courses regarding "implementation"; failure of establishing communication with friends regarding "student"; absence of internet regarding "impossibility", sound problems regarding "technical" and lack of communication regarding "instructor". Determining the problems is a step to their solutions in learning and teaching environment

\section{Introduction}

Distance education is a process of planned teaching learning that occurs in a different place from the normal learning setting and requires communication and a special corporate organization via technologies (Moore \& Kearsley, 2012). The definition of distance education has four components: a. Corporate basis b. Interactive telecommunication c. Data, sound and video sharing (learning experiences) d. Separation of teacher and student (Simonson, Smaldino, Albright \& Zvacek, 2008). Distance education is a concept which pertains to increasing the quality of education to develop student's learning (Burns, 2011).

Distance education in which the antecedent practices were based on mail correspondence technologies, with advances in technology, has continued with the use of pre-recorded media, two-way audio, two-way audio with graphics, one-way video, two-way audio / one-way video, two-way audio / video and desktop two-way audio / video technologies (Simonson et al., 2008). The rise of internet has brought out the concept of electronic learning by changing

\footnotetext{
*Correspondency: gerturk@ahievran.edu.tr
} 
the mode of delivery of learning and knowledge (Mahmud, 2010). Although there are semantic differences between concepts such as distance education, electronic learning, internet-based education and online learning, which have gained ground in the literature in the course of time, these concepts are correlated. For example, online learning is a version of distance education (Bates, 2018).

Together with the development of digital technologies aimed at offering distance courses, new educational opportunities such as open educational resources and massive open online courses have emerged for larger masses to access education (Sayk1l1, 2018). In today's digital age, online learning, blended learning, social media and open learning are critical developments for an effective teaching (Bates, 2018). Also, the widespread utilization of mobile learning tools has added a different dimension to distance education. The utilization of mobile learning tools in distance education has positive impacts on learner's motivation, selfregulation, control and personalization of learning environment (Sönmez, Göçmez, Uygun \& Ataizi, 2018). However, as teaching by using new technologies requires a variety of skills that most educators are not familiar with, the educators need to be trained on how to use these new devices and how to integrate them into their own implementations (Makoe, 2012). In addition, students should be prepared and motivated for distance education lessons that are greatly widespread and designed in different models (Bertiz \& Kocamankaroğlu, 2020).

\section{Problems faced in distance education}

Distance education offers individuals educational environments independent from time and space with the support of advancing web-based platforms and technologies (Bilgiç \& Tüzün, 2015). Institutions choose distance education for a number of reasons such as accessing learning and education, updating skill development, increasing cost effectiveness, increasing the quality of educational structure, improving the capacity of the system of education, balancing inequalities between age groups, providing education to specific target groups, providing emergency case training to target groups, expanding the capacity of education in new subject areas, associating working and family life with education and adding an international dimension to education (Moore \& Kearsley, 2012). However, institutions sometimes encounter obstacles and problems in technology integration. Ertmer (1999) identified first-order (external) and second-order (internal) barriers to the technological integration. First-order barriers are related with equipment, education, access, time and technical support; while second-order barriers (specific to teachers) are related with pedagogy, belief and personal preferences.

Davis, Gough and Taylor (2019) stated that student barriers to online learning might be misinterpretation of expectations, time management and interpersonal communication; while instructor barriers might be related to the identification of expectations, providing feedback and interpersonal relations. O'Doherty, Dromey, Lougheed, Hannigan, Last and McGrath (2018) stated in their research based on the literature that barriers to online learning in medical training might be time limitations, weak technical skills, inadequate infrastructure, lack of institutional strategies and support and negative attitudes of everyone involved. Burns (2011) mentioned three barriers to the web-based distance education implementations in teacher education: lack of high-speed internet and durable technology, lack of trainer and student skills and lack of support services.

In the literature, studies on the problems faced in learning environments such as distance education, online learning, electronic learning, are not adequate in number. The related 
studies have been conducted mostly with administrators and managers (Berge \& Muilenburg, 2000; Bilgiç \& Tüzün, 2015; Durak, Çankaya \& İzmirli, 2020), parents (Apriyanti, 2020), teachers (Fauzi, Hermavan \& Khusuma, 2020; Mailizar, Almanthari, Maulina \& Bruce, 2020; Rasmitadila et al., 2020) and students (Botha, 2011; Guven, Kurum \& Sağlam, 2012; Leontyeva; 2018; Mahmud, 2010; Muilenburg \& Berge, 2005; Özüdoğru \& Özüdoğru, 2017). These studies range from kindergarten to higher education, from health education to social sciences and to teacher education.

In the literature, there is a limited number of studies on the problems faced by students, parents, teachers and administrators in distance education during the Covid-19 period. Apriyanti (2020) found in their research that kindergarten and primary school parents face problems during the Covid-19 pandemic such as being unable to guide their children to learn and children's lack of concentration, unwillingness to learn, desire to go to school, inability to learn online and limited comprehension of the material. Fauzi et al. (2020) found in their research that teachers face problems in the Covid-19 pandemic such as lack of opportunities, network and internet use, planning, implementation and evaluation of learning, and collaboration with parents. Mailizar et al. (2020) found that teacher, school, curriculum and student were the four components of problems experienced by teachers in the Covid-19 period. Rasmitadila et al. (2020) found that teachers face problems in distance education implemented in the Covid-19 pandemic such as technical barriers, student's conditioning, student's participation in education and online education experience.

\section{Distance education during the Covid-19 Pandemic}

Coronavirus disease, also known as Covid-19, is a health problem today deeply affecting several areas like daily life, working life and the system of education in world. It first appeared in Wuhan City, China in December 2019, World Health Organization (WHO) (2021) declared Covid-19 is a global state of emergency on 30 January 2020 and a global pandemic on 11 March 2020. In order to reduce the spread of this life-threatening virus, specific limitations and rules such as travel restrictions and closure of restaurants, entertainment venues, theatres and cinemas have been imposed occasionally. One of these limitations is the prevention of face-to-face education. Distance education implementations have been used to reduce contact and to continue education. By this way distance education has started to be implemented from preschool education to higher education.

During the Covid-19 pandemic, institutions, administrators, educators, students and even parents have unpreparedly found themselves in the distance education process. Transition from face-to-face teaching methods to more indirect methods, has forced schools into a flow of learning which is full of complexities and limitations (Rasmitadila, 2020). This process has had a great impact on school, teachers and students (Mailizar et al., 2020). In this process, individuals inevitably have faced specific difficulties and obstacles in institutions. Students have been affected psychologically by school closures, lack of equipment to participate in courses, being unable to access online materials from home and being unable to leave home for a long time (Apriyanti, 2020). Also, the inadequate technological infrastructure of educational institutions can be considered another factor. Such factors are an obstacle to the success of the education implemented.

In order to gain success in distance education, problems should be revealed. Revealing these problems is important for removing, reducing or solving the barriers in distance education implementations to be conducted in the future. In addition, pre-service teachers may need to 
carry out their lessons in distance education in their prospective professional lives. Their distance education experiences may affect their attitudes toward future distance education. For this reason, it is important to examine the distance education process. This paper aims to reveal the individual, technological and economic problems faced by pre-service teachers in institutions training teachers during the Covid-19 pandemic period. The problems experienced by pre-service teachers throughout this emergency remote teaching period are not known. To that end it would be valuable to know what the pre-service teachers encountered in this situation. Thereupon the current research problem is as follows:

(1) Which problems have pre-service teachers faced in distance education during the Covid-19 pandemic?

\section{Materials and methods}

\section{Model}

The study used the case study method, which is among qualitative research methods. Case study is a qualitative approach that describes a case and reveals the themes of the case by using multiple sources of information and profoundly collecting information in order to produce a profound understanding related to a situation in real life, current system or in a specific time (Creswell, 2013). The case in this study is the distance education process which pre-service teachers were caught up in unprepared during the Covid-19 pandemic.

\section{Study group}

Study group of the present research comprised of 60 second-year pre-service teachers studying in the faculty of education in a mid-size state university in Turkey during the Spring term of the 2019-2020 academic year. Pre-service teachers were from the departments of Elementary Mathematics Teaching, Science Teaching, Preschool Teaching, Classroom Teaching, Psychological Counselling and Guidance and Social Studies Teaching. Of the participants, 26 were male and 34 were female.

\section{Environment}

Due to the Covid-19 pandemic, distance education has been implemented in universities during the spring term of the 2019-2020 academic year since March. In the university included within the scope of the study, the students have been involved in the distance education process via the learning management system of the university. As a synchronous video conference system has been integrated into the software, live courses are also available for every lesson. The duration of live courses is 30 minutes for each lesson. These live courses have been recorded and made available to the students from eight p.m. until eight a.m. daily. The hour limit was introduced to prevent a possible over loading on the servers during live lessons. In addition, the learning management system contains features such as adding subjects, adding acquisitions, texting, adding files, sharing materials, sharing announcements, giving homework and downloading. In the evaluation process, methods such as homework and exams were also applied via the learning management system. At the end of the term, opinions were received from the students regarding the process. 


\section{Data collection tool}

In the study the researcher prepared an interview form consisting of open-ended question to collect data. The form was created primarily by reviewing the relevant literature. Then a seven-item draft form was created. Opinions regarding the form were received from two experts in the areas of technology and language. After making the specified corrections, the form was applied for trial purposes to two students participating in the distance education process in order to determine whether there were unclear questions. The final version of the form had six questions. The questions on the form were: "1. What did you dislike most about the distance education process?", "2. Have you experienced any problems related to the distance education process? If you have, what were these problems?", "3. Was there anything missing in the distance education process? If so, what was it ?", "4. Would you like your next courses to continue to be delivered in the form of distance education? Why?", "5. What are your opinions about the simultaneous (live) lessons in distance education?" "6. What are your opinions about the evaluation processes (exam, homework etc.) in distance education?". The form was applied based on voluntary principle and online individually. Average time of answering was 20 minutes.

\section{Data analysis}

The content analysis method was used in the data analysis. Content analysis is often used to analyze data such as the one from interviews and observations, to systematize and often quantify data (Fraenkel, Wallen \& Hyun, 2012). The data acquired was transcribed by the researcher. The pre-service teachers were coded as P1, P2, and so on. The data were coded by two coders. A common coding table was created by discussing the different codes. Miles and Huberman's (1994) formula was used for a consensus between the coders. After obtaining adequate amount of consensus between the coders $(91 \%)$, the researcher continued the coding alone based on the common coding table. Miles and Huberman (1994) indicated that a consensus of $80 \%$ would be acceptable.

\section{Results}

In this study investigating the problems and barriers faced by pre-service teachers in a higher education institution during the distance education process implemented in the Covid19 pandemic, five themes and 29 codes were revealed as a result of the data analysis. The themes revealed in relation to the problems were: "Implementation", "Student", "Impossibility", "Technical" and "Instructor".

Table 1. Themes and codes revealed as a result of the analysis

\begin{tabular}{ll}
\hline Theme & Number of Code \\
\hline Implementation & 7 \\
Student & 7 \\
Impossibility & 6 \\
Technical & 5 \\
Instructor & 4 \\
\hline
\end{tabular}

Examining Table 1 it is understood that the implementation theme has seven codes, the impossibility theme has six codes, the technical theme has six codes, the instructor theme has four codes and the student theme has seven codes, which were revealed as a result of the analysis. It makes a total of 29 codes. 


\section{Problems related to implementation}

The implementation theme obtained as a result of the data analysis represents the problems related to the implementation of distance education. There are seven codes under this theme. Frequency indicates the number of participants revealing the relevant code. Table 2 demonstrates that the pre-service teachers mainly reported problems such as lack of time spared for live courses $(\mathrm{f}=45)$ and excessive workload due to homework $(\mathrm{f}=34)$ at the point of implementation.

Table 2. Codes and frequencies related to the implementation theme

\begin{tabular}{lll}
\hline Theme & Code & Frequency \\
\hline & Lack of time spared for live courses & 45 \\
& Excessive workload due to homework & 34 \\
& Implementation's inadequacy for major area courses & 15 \\
Implementation & Uncertain evaluation system & 12 \\
& Lack of time spared for homework & 8 \\
Limited access to registered courses & 5 \\
\hline
\end{tabular}

Examples to the pre-service teachers' views on the most frequently encountered problems in the implementation process are as follows. The pre-service teachers were named as P1, P2, and so on.

P10: The course hours should have been longer. As the course was taught too superficially in 30 minutes, I had a great difficulty understanding the subjects.

P51: The homework was too much. Some of our teachers had given us homework as if we had no other homework to do. We had a difficulty catching up with them. As the given time was too short and the homework was too much, we became exhausted.

\section{Problems related to students}

The student theme obtained as a result of the data analysis represents the problems individually faced by students during the distance education process. There are seven codes under this theme. As can be seen through Table 3 the pre-service teachers mainly reported individual problems pertaining to students such as being unable to establish communication with friends ( $\mathrm{f}=17)$ and being unable to be focused $(\mathrm{f}=13)$.

Table 3. Codes and frequencies related to the student theme

\begin{tabular}{lll}
\hline Theme & Code & Frequency \\
\hline & Inability to communicate with friends & 17 \\
& Inability to focus & 13 \\
Not feeling the classroom atmosphere & 10 \\
Student & Being not accustomed to the system & 9 \\
& Lack of knowledge, skills and attitudes & 7 \\
& Feeling the need to socialize & 6 \\
\hline
\end{tabular}

Examples to views on the individual problems related to students, are as follows: 
P7: ...Having group homework. We weren't able to establish a healthy communication with our friends in the group.

P39: ... When we have classes in the virtual environment, I can't fully concentrate on the lesson. I can't join the class unless I have the internet, which makes me get estranged from the lessons.

\section{Problems related to impossibility}

The impossibility theme obtained as a result of the data analysis represents the impossibilities faced during the distance education process. There are six codes under this theme. Examining Table 4; the pre-service teachers mainly reported problems related to impossibilities such as the lack of internet $(\mathrm{f}=20)$ and the lack of computer $(\mathrm{f}=14)$.

Table 4. Codes and frequencies related to the impossibility theme

\begin{tabular}{lll}
\hline Theme & Code & Frequency \\
\hline \multirow{3}{*}{ Impossibility } & Lack of internet & 20 \\
& Lack of computer & 14 \\
& Limited internet & 12 \\
& Unsuitable smart phone & 8 \\
& Inequality of opportunity & 7 \\
\hline
\end{tabular}

Examples to the views on the most frequently encountered impossibilities, are as follows.

P15: ... At some point I had a great difficulty because we didn't have opportunities like internet connection. This bothered me a lot. I couldn't use the outside sources either because of the virus, which made me think that I failed in accomplishing my homework.

P28: As I have no computer or laptop, I had a difficulty doing my homework on the phone. I had no other problems.

\section{Technical problems}

The technical problems theme obtained as a result of the data analysis represents the technical problems faced during distance education. There are five codes under this theme. As can be found through Tale 5 below the pre-service teachers mainly reported technical problems such as sound problems $(\mathrm{f}=11)$ and connection problems to the live lesson $(\mathrm{f}=10)$.

Table 5. Codes and frequencies related to the technical theme

\begin{tabular}{lll}
\hline Theme & Code & Frequency \\
\hline \multirow{3}{*}{ Technical } & Sound problems & 11 \\
& Connection problems to the live lesson & 10 \\
& File upload problems & 9 \\
& System login problems & 8 \\
\hline
\end{tabular}

Codes and frequencies related to the most frequently encountered technical problems, are as follows: 
P26: ...I occasionally had connection and sound problems.

P24: Yes, either the system sent me off during the class or I was unable to log in. The sound had echoes. It kept coming and going.

\section{Problems related to instructor}

The instructor theme obtained as a result of the data analysis represents the problems faced by pre-service teachers related to the instructor. There are four codes under this theme. According to Table 6the pre-service teachers mainly reported problems related to their instructor such as being unable to establish communication with the instructor $(f=10)$ and the instructor's lack of knowledge, skills and attitudes regarding the distance education process $(\mathrm{f}=6)$.

Table 6. Codes and frequencies related to the instructor theme

\begin{tabular}{lll}
\hline Theme & Code & Frequency \\
\hline \multirow{3}{*}{ Instructor } & Lack of communication & 10 \\
& Lack of knowledge, skills and attitudes & 6 \\
& Not getting feedback & 5 \\
& Being not accustomed to the system & 5 \\
\hline
\end{tabular}

Examples to the views on the most frequently encountered problems related to instructor, are as follows:

P9: I wasn't able to establish communication with the teachers much or receive messages and feedback related to the course. The live courses had time limitation, which I did not like at all.

P29: I had a problem with contacting the instructor. When there was a problem with homework, I wasn't able to immediately contact them. I couldn't report these problems until the time of synchronous courses came.

\section{Conclusion and Discussion}

The study revealed the problems experienced by pre-service teachers in a higher education institution during the distance education process implemented due to the Covid-19 pandemic. In the study, which was carried out with a qualitative approach, the problems faced by the pre-service teachers were collected under the themes of implementation, student, impossibility, technical and instructor. Under each theme were relevant codes. Similarly the study conducted by Mailizar et al. (2020) with teachers in the Covid-19 pandemic, approached the barriers at four components as teacher, school, curriculum and student. Rasmitadila et al. (2020) found the difficulties faced by teachers during distance education in the Covid-19 pandemic as technical barriers, student's conditioning, student's participation in education and online education experience. Fauzi et al. (2020) demonstrated that teachers experience a variety of problems during the Covid-19 pandemic such as lack of opportunities in online learning applications, network and internet use, teacher's planning, implementation and evaluation and collaboration with parents.

The first of the themes revealed at the end of the study was implementation. At the point of the implementation of distance education, the pre-service teachers stated that they experienced problems such as lack of time spared for live courses, excessive work load due to homework, implementation's inadequacy for major area courses, ambiguous evaluation 
system, lack of time spared for homework, limited access to registered courses and lower interaction. Having 30-minute live courses a week during distance education, might have left the processes of feedback, interaction and question-answer incomplete. Video implementations are important for communication and feedback in terms of addressing the emotional needs of students during Covid-19 (Kaplan-Rakowski, 2020). In addition, the evaluation was mainly conducted as homework and while there used to be a midterm and a final exam during face-to-face education, there came two midterm exams and a final exam, which led to excessive work-load. Also, in homework the instructors did not share the evaluation rubric with the students, which caused the students to have uncertainties about the evaluation. The live courses recorded were kept open from eight p.m. until eight a.m. to prevent a possible over loading on the servers during the class, which was evaluated as an access limit for the students. Similarly, Mahmud (2010) found that university students consider the difficulty of interaction a barrier to distance education.

The second of the themes revealed at the end of the study was student. The student theme contains problems faced by pre-service teachers individually. These problems are being unable to establish communication with friends, being unable to focus, not feeling the classroom atmosphere, being not accustomed to the system, lack of knowledge, skills and attitudes, feeling the need to socialize and remaining passive. A variety of training and orientation programs can be conducted to solve the problems related to students. When students are transferred from face-to-face education to a classroom supported by specific technologies for distance education, they will need an orientation to get used to the instructor's expectations as much as they need course materials and equipment (Davis et al., 2019). Similarly, Mahmud (2010) found that university students consider the unwillingness to change environment in distance education a barrier to distance education. Davis et al. (2019) found the student barriers in online learning to be a misinterpretation of expectations, time management and interpersonal communication. Mailizar et al. (2020) found in their research that the lack of knowledge, skills and devices, internet connection, irrelevance and issues with system access were the problems experienced by teachers and students in the Covid-19 pandemic.

The third of the themes revealed at the end of the study was impossibility. The impossibilities experienced by pre-service teachers in the process were lack of internet, lack of computer, limited internet, unsuitable smart phone for the courses, inequality of opportunity and lack of equipment like microphone and headphones. Pre-service teachers were caught up unprepared in this process and had to participate with limited opportunities. In addition, while some preservice teachers were in the city centre, some tried to participate from villages with various internet problems. Likewise, whereas some of them participated with their computers and prepared homework, some tried to participate in the classes and prepare homework by connecting via phones or tablets with inadequate equipment. These might have also caused them to evaluate as inequalities of impossibility. Similarly, Apriyanti (2020) stated that lack of internet access and digital tools in villages or rural areas was a barrier to online courses. Also, Mahmud (2010) found that university students consider the scarcity of information and communication technologies resources a barrier to distance education.

Another theme revealed at the end of the study was technical problems. They were live course connection problems, file upload problems, system login problems, video problems. These problems may have arised from the devices used by the pre-service teachers, internet speed and capacity or system-related current moods. Mahmud also (2010) found that university students consider the internet connection problems a barrier to distance education. 
The last of the study themes was related to instructors. They were lack of communication, being unable to receive feedback, lack of knowledge, skills and attitudes and not being accustomed to the system. Another group of stakeholders caught up unprepared in the distance education system is instructors. Durak, Çankaya and İzmirli (2020) concluded that the most difficult situation was the training of instructors in the distance education process in higher education institutions during the Covid-19 pandemic period. Mailizar et al. (2020) stated that teachers experience problems in the Covid-19 pandemic in regard to knowledge, skill, self-confidence, experience, efficacy and convenience. Also, Makoe (2012) found in their research that instructors being accustomed to the former teaching methods and their lack of teaching design speciality for new methods and lack of technological knowledge and skills were barriers to their technological integration. Davis, Gough and Taylor (2019) determined the barriers related to instructors in online learning are about establishing expectations, providing feedback and interpersonal relations. Most instructors have started to experiment with a new approach as they did not have the possibility to teach with the technologies used in distance education before the pandemic (Bonk, 2020). Amhag, Hellström and Stigmar (2019) found that teacher educators cannot use digital technology for pedagogical purposes. It may be useful to provide applied training opportunities for instructors regarding the technologies used in distance education. Increasing the competences and experiences of instructors will positively affect their attitudes. In their research, Borup and Evmenova (2019) provided a 6-7week vocational development course to prepare lecturers to online courses. They stressed that the course was effective on exceeding the barriers to change, as has also been specified by Ertmer (1999).

In the literature there had been studies on barriers and problems related to subjects such as distance education and online learning even before Covid-19. Botha (2011) found that students taking the social services class in university consider inadequate service delivery, personal barriers and lack of resource as barriers to distance learning. Özüdoğru and Özüdoğru (2017) stated that students faced problems with internet connection during exams, inability to concentrate, not being accustomed to different methods, receiving no messages or mail for notifications in a web based instruction research. According to a study conducted by Muilenburg and Berge (2005) with students, the barriers to online learning are pertinent to administrative problems, student motivation, social interaction, technical skills, academic skills, time and support for research, cost and internet access and technical problems. Guven, Kurum and Sağlam (2012) collected the problems faced in the teaching implementation lesson which is conducted as distance education, under the themes such as preparing a teaching practice file, planning, time, mode of practice, classroom management, school of practice, teacher of practice and control. Leontyeva (2018) investigated the main barriers (internal-external) to using distance education for educational purposes in universities. Internal factors: unpreparedness of teachers and parents, lack of necessary skills to implement computer-based online learning systems, interaction with faculty and teachers and lack of online supervisors. External factors: limited resources, unequally distributed marketing advantages, inappropriate administrative structure and lack of innovative physical facilities. Examining these studies in the literature; some of them obtained similar results with those of this study in regard to themes like impossibility, student, instructor, technical, interaction, time, access, internet connection, while some of them obtained different results such as lack of institution, administration, faculty, language, accreditation, management and supervisor.

The study reveals the problems experienced by pre-service teachers in the distance education process. Determining the problems is a step to finding and creating their solutions. During this pandemic, educators can realize the difficulties faced by students and create a humanizing 
pedagogy approach that is inclusive and sensitive to learner needs (Karakaya, 2021). It is necessary to support the knowledge, skills, attitudes and tendencies of pre-service teachers in order to prepare them for their profession and remove the barriers to online teaching (Borup \& Evmenova, 2019). Distance education is an important part of the vocational development of pre-service and in-service teachers in both developing and developed countries (Burns, 2011). Our system of education needs teachers who are competent in the rapidly developing and changing context of information equipped with the sense of combining theory and practice (Guven, Kurum \& Sağlam, 2012).

\section{Recommendation}

Distance education has always carried problems; however, some of the problems revealed as a result of the study are related specifically to Covid-19 pandemic period. It is necessary to take measures to prevent problems that may arise in such pandemics or in emergency situations. Based on the study it is possible to investigate the problems faced by teachers, parents and directors in distance education during the Covid-19 pandemic which continues to spread across the world, via different methods. Because the reason is the problems revealed in student views seem also to be related with other shareholders. In addition, the study is limited to the faculty of education in a higher education institution. The case can be investigated in other faculties or units as well. Similarly, student, teacher, parent and director views can be examined at the primary education level via various methods. Lastly it is believed that solving the problems revealed in the study will also be valuable to the implementers.

\section{References}

Apriyanti, C. (2020). Distance learning and obstacles during Covid-19 outbreak. Jurnal Ilmiah Pendidikan Dasar, 7(2), 68-83.

Bates, A. W. T. (2018). Teaching in a digital age: Guidelines for designing teaching and learning. Tony Bates Associates Ltd, Vancouver BC.

Berge, Z., \& Muilenburg, L. (2000). Barriers to distance education as perceived by managers and administrators: Results of a survey. In M. Clay (Ed.), Distance learning administration annual 2000. Baltimore, MD: University of Maryland-Baltimore. Retrieved from: https://mdsoar.org/handle/11603/16539.

Bertiz, Y. \& Kocaman Karoğlu, A. (2020). Distance education students' cognitive flexibility levels and distance education motivations. International Journal of Research in Education and Science (IJRES), 6(4), 638-648.

Bilgiç, H. G., \& Tüzün, H. (2015). Yükseköğretim kurumları web tabanlı uzaktan eğitim programlarında yaşanan sorunlar [The problems experienced web-based distance education programs in higher education institutes]. Açıkögretim Uygulamaları ve Araştırmaları Dergisi [Journal of Open Education Applications and Research], 1(3), 26-50.

Bonk, C. J. (2020) Pandemic ponderings, 30 years to today: Synchronous signals, saviors, or survivors?, Distance Education, 41(4), 589-599.

Borup, J., \& Evmenova, A. S. (2019). The effectiveness of professional development in overcoming obstacles to effective online instruction in a college of education. Online Learning, 23(2), 1-20.

Botha, P. (2011). Obstacles and facilitative opportunities while studying social work within an open and distance learning context. Social Work/Maatskaplike Werk, 47(4), 451461. 
Burns, M. (2011). Distance education for teacher training: Modes, models and methods. Washington: Education Development Center Inc.

Chen, B. (2009). Barriers to adoption of technology-mediated distance education in highereducation institutions. Quarterly Review of Distance Education, 10(4), 333-338.

Creswell, J. W. (2013). Qualitative inquiry \& Research desing: Choosing among five approaches. United States of America: SAGE.

Davis, L. N., Gough, M., \& Taylor, L. L. (2019) Online teaching: Advantages, obstacles and tools for getting it right. Journal of Teaching in Travel \& Tourism, 19(3), 256-263.

Durak, G., Çankaya, S., \& İzmirli, S. (2020). Examining the Turkish universities' distance education systems during the COVID-19 Pandemic. Necatibey Faculty of Education Electronic Journal of Science and Mathematics Education, 14(1), 787-809.

Ertmer, P. A. (1999). Addressing first- and second-order barriers to change: Strategies for technology integration. Educational Technology Research and Development, 47(4), 47-61

Fauzi, I., \& Khusuma, I. H. S. (2020). Teachers' elementary school in online learning of Covid-19 pandemic conditions. Jurnal Iqra': Kajian Ilmu Pendidikan, 5(1), 58-70.

Fraenkel, J. R., Wallen, N. E., \& Hyun, H. H. (2012). How to design and evaluate research in education. New York: McGraw-hill.

Guven, M., Kurum, D., \& Saglam, M. (2012). Evaluation of the distance education preservice teachers' opinions about teaching practice course (Case of Izmir City). Turkish Online Journal of Distance Education, 13(1), 112-127.

Kaplan-Rakowski, R. (2020). Addressing students' emotional needs during the COVID-19 pandemic: a perspective on text versus video feedback in online environments. Education Tech Research Dev. https://doi.org/10.1007/s11423-020-09897-9

Karakaya, K. (2021). Design considerations in emergency remote teaching during the COVID-19 pandemic: A human-centered approach. Education Tech Research Dev., 69, 295-299. https://doi.org/10.1007/s11423-020-09884-0

Leontyeva, I. A. (2018). Modern distance learning technologies in higher education: Introduction problems. Eurasia Journal of Mathematics, Science and Technology Education, 14(10), em1578.

Mahmud, K. (2010). E-learning for tertiary level education in least developed countries: Implementation obstacles and way outs for Bangladesh. International Journal of Computer Theory and Engineering, 2(2), 150-155.

Mailizar, Almanthari, A., Maulina, S., \& Bruce, S. (2020). Secondary school mathematics teachers' views on e-learning implementation barriers during the Covid-19 Pandemic: The case of Indonesia. Eurasia Journal of Mathematics, Science and Technology Education, 16(7), em1860.

Makoe, M. (2012). Teaching digital natives: Identifying competencies for mobile learning facilitators in distance education. South African Journal of Higher Education, 26(1), 91-104.

Miles, M. B., \& Huberman, A. M. (1994). Qualitative data analysis: An expanded sourcebook. Thousand Oaks, CA: Sage.

Moore, M., \& Kearsley, G. (2005). Distance Education: A Systems View. Belmont, CA: Wadsworth, Cengage Learning.

Muilenburg, L. Y. \& Berge, Z. L. (2005) Student barriers to online learning: A factor analytic study. Distance Education, 26(1), 29-48.

O’Doherty, D., Dromey, M., Lougheed, J., Hannigan, A., Last, J., \& McGrath, D. (2018). Barriers and solutions to online learning in medical education-an integrative review. BMC Medical Education, 18(1), 130. 
Özüdoğru, G., \& Özüdoğru, A. (2017). An Investigation of web based instruction experiences of physiotherapy and rehabilitation students. Ahi Evran University Journal of Kirşehir Education Faculty, 18(3), 865-879.

Rasmitadila, Aliyyah, R. R., Rachmadtullah, R., Samsudin, A., Syaodih, E., Nurtanto, M., \& Tambunan, A. R. S. (2020). The Perceptions of primary school teachers of online learning during the COVID-19 Pandemic period: A case study in Indonesia. Journal of Ethnic and Cultural Studies, 7(2), 90-109.

Sayk111, A. (2018). Distance education: Definitions, generations, key concepts and future directions. International Journal of Contemporary Educational Research, 5(1), 2-17.

Simonson, M., Smaldino, S., Albright, M. \& Zvacek, S. M. (2008). Teaching and learning at a distance: Foundations of distance education. Information Age Publications, Chorlatte, North Carolina.

Sönmez, A., Göçmez, L., Uygun, D., \& Ataizi, M. (2018). A review of current studies of mobile learning. Journal of Educational Technology \& Online Learning, 1(1), 13-27.

World Health Organization (WHO) (2021). Coronavirus disease (COVID-19) pandemic. Retrieved from https://www.euro.who.int/en/health-topics/healthemergencies/coronavirus-covid-19/novel-coronavirus-2019-ncov on 28.01.2021. 